\title{
A tőkepiaci eszközárazási modell három időszakos kiterjesztése
}

\begin{abstract}
Jelen tanulmányban megmutatjuk, hogy a tökepiaci eszközárazási modell (CAPM) levezethető egy három időszakos általános egyensúlyelméleti modellből is, ami felveti a CAPM hosszú távú alkalmazhatóságát is. Bebizonyítjuk továbbá, hogy a modellünk Pareto-hatékony megoldást eredményez.*

Journal of Economic Literature (JEL) kód: D53, G12.
\end{abstract}

A tőkepiaci eszközárazási modell - amelyre szinte mindig CAPM-ként (Capital Asset Pricing Model) hivatkozik az irodalom - pontos becslést ad egy adott eszköz kockázata és várható hozama közötti kapcsolatra. Ez a modell tulajdonképpen a kockázatos eszközök egyensúlyi várható hozamára vonatkozó becslések összessége.

A CAPM-egyenlet levezethető egy két időszakos általános egyensúlyelméleti modellből is, ami megnyugtató elméleti megalapozottságot nyújt a modern portfóliókezelés alapvető eszközéül szolgáló várható hozam-béta kapcsolathoz.

Jelen tanulmányunkban a fogyasztási alapú eszközárazás modelljének három időszakos kiterjesztését vizsgáljuk. Ennek a kiterjesztésnek számos területen lehetnek rendkívül jelentős alkalmazásai. A minimum három időszak elengedhetetlen például a hoszszú lejáratú pénzügyi eszközök modellezéséhez, illetve az időinkonzisztens viselkedés beépítéséhez is. Bemutatunk egy három időszakos, egytermékes, intertemporális általános egyensúlyelméleti modellt, a pénzügyekből már jól ismert CAPM árazási képlet fogyasztási alapú változatát (Consumption-Based Capital Asset Pricing Model, CCAPM). Bebizonyítjuk, hogy a fogyasztásalapú CAPM árazási formulája levezethető az általunk felvázolt három időszakos modellből is, amelyre a szakirodalomban még nincsen példa.

A modellünk alapjául szolgáló két időszakos, már ismert árazási formulákat jól leírja például LeRoy-Werner [2001] könyve, amelyre a tanulmányban több ponton építünk. Az általános egyensúlyelméleti megközelítés lehetőséget nyújt a piacok hatékonyságának vizsgálatára is.

*A szerzők köszönik a Nemzeti Kutatási, Fejlesztési és Innovációs Hivatal támogatását (FK 125126).

Habis Helga, Budapesti Corvinus Egyetem (e-mail: helga.habis@uni-corvinus.hu).

Perge Laura, Budapesti Corvinus Egyetem (e-mail: laura.perge@gmail.com).

A kézirat első változata 2020. január 27-én érkezett szerkesztőségünkbe.

DOI: http://dx.doi.org/10.18414/KSZ.2020.4.379 
Tanulmányunk másik fő eredménye, hogy a jóléti közgazdaságtan első tétele a három időszakos modellünkben is teljesül.

\section{Az intertemporális pénzügyi-gazdasági modell felépítése}

A könnyebb áttekinthetőség, rendszerezettség és az egyértelmüsítés okán jelen fejezetben összefoglaljuk a használt fogalmak tanulmánybeli értelmezését, ismertetjük a főbb definíciókat, feltevéseket, melyek szükségesek a modell müködéséhez. Ezen struktúra létrehozásában elsősorban Habis-Herings [2011]-re támaszkodunk.

Tekintsünk egy három időszakos modellt, ahol a periódusokat $t \in\{0,1,2\}=T$ jelöli. Minden $t>0$ időszakban egy esemény a véges sok közül teljesül. Minden $s \in \mathcal{S}$ állapotban megvalósuló eseményt a $t$-edik periódusban $s_{t} \in \mathcal{S}_{t}$-vel jelölünk, ahol az $\mathcal{S}_{t}$ számossága $S_{t}$ és $\mathcal{S}=\bigcup_{t} \mathcal{S}_{t}$ minden $t \in T$ esetén. A $t=0$-ban definiáljuk ezt $s_{0}=0$-val. Fejezzük ki $s_{t}^{+}$-szal az $s_{t}$ utódait, azaz az $s_{t}$-t követö állapotokat minden $t=0$, 1-re, és $s_{t}^{-}$-szal az $s_{t}$ elödeit (az $s_{t}$-t megelöző állapotokat) minden $t=1,2$ esetén. Minden periódusban van egyetlen, nem tartós fogyasztási jószág.

A neoklasszikus közgazdaságtan feltevéseinek megfelelően racionális, azaz haszonmaximalizáló (önérdekkövető) viselkedést feltételezünk. A racionális fogyasztók tökéletesen elörelátnak (perfect foresight), aminek a lényege, hogy döntéshozataluk időpontjában meglevő tudásuk elégséges ahhoz, hogy optimális döntést hozzanak. A gazdaságban véges számú, $h \in H$ racionális fogyasztó van jelen. Minden $h \in H$ alany rendelkezik $\left(e_{s_{t}}^{h}\right)_{s_{t} \in\{0\} \cup \mathcal{S}_{1} \cup \mathcal{S}_{2}} \in \mathbb{R}^{\left(S_{1}+S_{2}+1\right)}$ indulókészlettel és preferenciákkal a $\left(c_{s_{t}}^{h}\right) \in \mathbb{R}^{\left(S_{1}+S_{2}+1\right)}$ fogyasztási kosarakra, ahol $s_{t} \in\{0\} \cup \mathcal{S}_{1} \cup \mathcal{S}_{2}$.

Minden szereplö preferenciáját egy Neumann-Morgenstern-féle hasznossági függvény reprezentálja, amely az idő függvényében elkülöníthető részekre bontható. A 0 -adik időszaki hasznossági függvény a racionális fogyasztó esetében

$u^{h}\left(c^{h}\right)=v_{0}^{h}\left(c_{0}^{h}\right)+\delta_{1} \sum_{s_{1} \in \mathcal{S}_{1}} \rho_{s_{1}} v_{s_{1}}^{h}\left(c_{s_{1}}^{h}\right)+\delta_{1} \delta_{2} \sum_{s_{1} \in \mathcal{S}_{1}} \rho_{s_{1}} \sum_{s_{2} \in s_{1}^{+}} \rho_{s_{2}} v_{s_{2}}^{h}\left(c_{s_{2}}^{h}\right)$

ahol $\rho_{s_{1}}$ jelöli az $s_{1}$ esemény bekövetkezésének objektív valószínüségét, $\rho_{s_{2}}$ pedig $s_{2}$ elöfordulásának feltételes valószínüsége, és feltétele, hogy $s_{1}$ bekövetkezett. A $\delta_{t}$ egy 1 idöszakos diszkontfaktor, és $v_{t}^{h}$ egy Bernoulli-féle hasznossági függvény.

Tanulmányunkban el fogjuk fogadni az 1. FELTEvÉsT.

1. FELTÉTEL • Feltételezzük, hogy $\rho_{s_{t}}>0$ minden $s_{t} \in S_{t}$ esetén, és $\sum_{s_{1} \in \mathcal{S}_{1}} \rho_{s_{1}}=1$, $\sum_{s_{2} \in \mathcal{S}_{2}} \rho_{s_{2}}=1, \delta_{1}, \delta_{2}>0$, a valószínüségek és a diszkontfaktorok megegyeznek a szereplök között, és a Bernoulli-féle hasznossági függvény szigorúan növekvő. Továbbá $c^{h} \in X^{h}$, ahol $X^{h} \subset \mathbb{R}^{1+S_{1}+S_{2}}$ a $h$ szereplő fogyasztási vektora.

Vegyük észre, hogy a $\rho_{s_{t}}>0$ feltétel mindössze annyit jelent, hogy a gazdasági szereplők csak azokat a jövőbeli kimeneteleket veszik figyelembe, amelyeknek az objektív bekövetkezési valószínüsége pozitív, azaz a valószínütlen események nem befolyásolják a hasznosságukat. További egyszerüsítő feltevésünk, hogy minden gazdasági szereplö azonos diszkontfaktorokat alkalmaz, és nincs telítődési pontjuk. 
Jelöljük $J_{s_{t}}$-vel a pénzügyi eszközöket minden egyes $s_{t} \in\{0\} \cup \mathcal{S}_{1}$ esetén. Adott $s_{t}$ állapotban létező eszközök összessége legyen $\mathcal{J}_{s_{t}}$. Minden $j$-edik eszköz $d_{s_{t+1}, j}$ (véletlenszerü) osztalékokat fizet ki $s_{t+1} \in s_{t}^{+}$világállapot bekövetkezésekor. Az osztalékok vektora $d_{s_{t}}=\left(d_{s_{t}, 1}, \ldots, d_{s_{t}, J_{s_{t}}}\right)$, ahol $s_{t} \in \mathcal{S}_{1} \cup \mathcal{S}_{2}$, és a kifizetési mátrixok $A_{s_{t}}=\left(d_{1}, \ldots, d_{s_{s_{t}}}\right) \in \mathbb{R}^{\left|s_{t}^{+}\right| \times I_{s_{t}}}$, ahol $s_{t} \in\{0\} \cup \mathcal{S}_{1}$. A j-edik eszköz ára $s_{t} \in\{0\} \cup \mathcal{S}_{1}$ világállapot esetén $q_{s_{t}, j} \in \mathbb{R}$. Az eszközárak vektorát $q_{s_{t}}=\left(q_{s_{t}, 1}, \ldots, q_{s_{t}, J_{s_{t}}}\right)$ jelzi, és az árak összessége az állapotok során $q=\left(q_{s_{t}}\right)_{s_{t} \in\{0\} \cup \mathcal{S}_{1}}$. Feltételezzük, hogy az eszközök piacán a nettó túlkínálat nulla. Minden $s_{t} \in\{0\} \cup \mathcal{S}_{1}$ világállapotban a $h$-adik szereplő $\theta_{s_{t}}^{h}=\left(\theta_{s_{t}, 1}^{h}, \theta_{s_{t}, 2}^{h}, \ldots, \theta_{s_{t}, s_{s_{t}}}^{h}\right) \in \mathbb{R}^{I_{s_{t}}}$ portfóliót tart.

$\mathrm{Az} \mathcal{E}=\left[\left(u^{h}, e^{h}\right)_{h=1, \ldots, H} ;\left(A_{s_{t}}\right)_{s_{t} \in\{0\} \cup \mathcal{S}_{1}}\right]$ pénzügyi gazdaságot az alanyok hasznossági függvényei és készletei, valamint a kifizetési mátrixok határozzák meg.

Az 1. DEFiníció a tökéletes verseny klasszikus definícióját mutatja be. A fogyasztók egy korlátos haszonmaximalizálási feladat alapján határozzák meg a fogyasztási pályájukat és a portfóliójukat, azaz költségvetési és megvalósíthatósági korlátok mellett döntenek.

1. DEFINíció - A tökéletes versenyzői egyensúly egy $\mathcal{E}$ gazdaság portfólióállománya $\left[\theta^{*}=\left(\theta^{1 *}, \theta^{2 *}, \ldots, \theta^{H *}\right) \in \mathbb{R}^{H \times J \times\left(s_{1}+1\right)}\right]$, fogyasztásai $\left[c^{*}=\left(c^{1 *}, c^{2 *}, \ldots, c^{H *}\right) \in \mathbb{R}^{H \times\left(s_{1}+s_{2}+1\right)}\right]$ és $\forall s_{t} \in\{0\} \cup \mathcal{S}_{1}$ esetre $J_{s_{t}}$ eszközei és az ezekhez tartozó eszközárak $\left[q_{s_{t}}=\left(q_{s_{t}, 1}, \ldots, q_{s_{t}, J_{s_{t}}}\right)\right]$ által meghatározott, és kielégíti az alábbi feltételeket:

1. $h=1,2, \ldots, H$ fogyasztó esetén

$\left(c^{h *}, \theta^{h *}\right) \in \arg \max _{c^{h} \in X^{h}, \theta^{h} \in \mathbb{R}^{I \times\left(S_{1}+1\right)}} u^{h}\left(c^{h}\right), \quad$ amelyre fennáll

$c_{0}^{h}+q_{0} \theta_{0}^{h}=e_{0}^{h}$,

$c_{s_{1}}^{h}+q_{s_{1}} \theta_{s_{1}}^{h}=e_{s_{1}}^{h}+d_{s_{1}} \theta_{0}^{h} \quad s_{1} \in \mathcal{S}_{1} \quad$ esetén, és

$c_{s_{2}}^{h}=e_{s_{2}}^{h}+d_{s_{2}} \theta_{s_{2}^{-}}^{h} \quad s_{2} \in \mathcal{S}_{2} \quad$ esetén,

2.

$\sum_{h=1}^{H} \theta^{h *}=0$,

3.

$\sum_{h=1}^{H} c^{h *}=\sum_{h=1}^{H} e^{h}$.

Látható, hogy a harmadik feltétel mindig teljesül, ha az első és a második is teljesül. Ha az 1. FELTÉTEL teljesül (azaz a szereplők szigorúan növekvő hasznossági függvényekkel rendelkeznek), az egyensúlyi árak kizárják az arbitrázslehetőségeket az alábbi, 2. DEFinícıó által meghatározott módon. 
2. DEFINÍció - A q eszközárak arbitrázsmentesek, ha nincs olyan $\theta^{h}=\left(\theta_{s_{t}}^{h}\right)_{s_{t} \in\{0\} \cup \mathcal{S}_{1}}$, amelyre igaz, hogy

$q_{0} \theta_{0}^{h} \leq 0$

$\forall s_{t} \in \mathcal{S}_{1} \cup \mathcal{S}_{2}: q_{s_{t}} \theta_{s_{t}}^{h} \leq A_{s_{t}^{-}} \theta_{s_{t}^{-}}^{h}$,

ahol legalább az egyik egyenlőtlenség szigorúan teljesül.

3. DEFINíció • A piacokat teljesnek nevezzük, ha minden $y \in \mathbb{R}^{S_{1}+S_{2}}$ jövedelemáramlás esetén létezik egy olyan $\left(\theta_{s_{t}}^{h}\right)_{s_{t} \in\{0\} \cup \mathcal{S}_{1}}$ portfólióterv, amely esetén

$\forall s_{1} \in \mathcal{S}_{1}: d_{s_{1}} \theta_{0}^{h}-q_{s_{1}} \theta_{s_{t}}^{h}=y_{s_{1}} ;$

$\forall s_{2} \in \mathcal{S}_{2}: d_{s_{2}} \theta_{s_{2}^{-}}^{h}=y_{s_{2}}$.

Azaz minden egyes $s_{t} \in\{0\} \cup \mathcal{S}_{1}$ világállapotra és $s_{t}$ közvetlen követőiben jelentkező tetszőleges kifizetéshez létezik egy portfólió, amely generálja ezeket a kifizetéseket. Ilyen portfólió akkor és csak akkor létezik, ha $A_{s_{t}}$ rangja $\left|s_{t}^{+}\right|{ }^{1}$

1. ÁLLÍTÁs • Ha nincsen arbitrázsra lehetöség a pénzügyi piacokon, és a piacok teljesek, akkor létezik egy egyedi, szigorúan pozitív, állapotokhoz tartozó árvektor $\left[\left(\pi_{s_{t}}\right)_{s_{t} \in\{0\} \cup \mathcal{S}_{1}} \in \mathbb{R}^{s_{1}+1}\right]$, amelyre igaz, hogy

$q_{s_{t}}=\pi_{s_{t}}^{\top} \cdot A_{s_{t}}$.

BizonyíTÁs • Az állítás bizonyítása megtalálható Magill-Quinzii [1996] könyvében.

Az alábbi két feltételt, valamint az öket követő jelölésmódot elfogadjuk és alkalmazzuk a dolgozat egészében:

1. Az 1-es eszköz kockázatmentes, tehát $d_{s_{t}, 1}=1 \forall s_{t} \in \mathcal{S}_{1} \cup \mathcal{S}_{2}$, és a hozama $R_{f}=1 / q_{s_{t}, 1}$,

2. és $\left\{c^{h} \in X^{h} \mid u^{h}\left(c^{h}\right) \geq u^{h}\left(e^{h}\right)\right\} \subset$ int $\left(X^{h}\right)$, ami biztosítja, hogy ne forduljon elő a fogyasztás szempontjából határponti megoldás egy szereplő maximalizálási problémája során.

$\mathrm{Az} E_{s_{t}}\left(c_{s_{t}^{+}}\right)$a $c_{s_{t}^{+}}$várható értéke, feltéve, hogy az $s_{t}$ világállapot bekövetkezett, azaz $E_{s_{t}}\left(c_{s_{t}^{+}}\right)=\sum_{s_{t+1} \in s_{t}^{+}} \rho_{s_{t}} c_{s_{t}}$.

\section{Hatékonyság}

A jóléti közgazdaságtan első tétele kimondja, hogy a teljes piacok egyensúlya a fogyasztások Pareto-hatékony feloszlását eredményezi. Egy felosztás Pareto-optimális, ha a teljes készletet lehetetlen olyan módon újra felosztani, hogy egy vagy több szereplő

\footnotetext{
${ }^{1} \mathrm{Az} A_{s_{t}}$ rangjára vonatkozó feltétel jelen modellbeli fontosságának részleteit lásd Habis-Herings [2011].
} 
jobban járjon, anélkül hogy bármelyik másik alany rosszabbul járna. Speciálisan, a fogyasztás egy $c^{h}$ allokációja Pareto-optimális, ha nem létezik olyan megvalósítható, alternatív $\bar{c}^{h}$ felosztása az erőforrásoknak, amely

$\sum_{h=1}^{H} \bar{c}^{h}=\sum_{h=1}^{H} e^{h}$

minden alany által gyengén preferált,

$u^{h}\left(\bar{c}^{h}\right) \geq u^{h}\left(c^{h}\right)$,

és szigorúan preferált legalább egy fogyasztó által úgy, hogy a (9) egyenlet szigorú egyenlőtlenségként teljesül legalább egy fogyasztóra.

2. ÁLLÍTÁs (A JÓLÉTI KÖZGAZDASÁGTAN ELSŐ TÉTELE) • Legyen $\left(\theta^{*}, c^{*}, q^{*}\right)$ egy versenyzöi egyensúly $\mathcal{E}$-ben. Ha az eszközök piaca teljes, akkor $c^{\star}$ Pareto-optimális.

BizonyíTÁs • A bizonyítást indirekt módon végezzük. Tegyük fel, hogy $c^{* h}$ az egyensúlyi fogyasztási allokáció a teljes piacon, és hogy létezik egy olyan megvalósítható $\tilde{c}^{h}$ elosztás, amelyre $u^{h}\left(\tilde{c}^{h}\right) \geq u^{h}\left(c^{* h}\right)$ minden $h$ esetén úgy, hogy az egyenlőtlenség szigorú valamennyi $h$-ra.

Felhasználva az 1. DEFiníció keretrendszerét, a $c^{* h}$ fogyasztási terv az $u^{h}\left(c^{h}\right)$ hasznosságot maximalizálja a költségvetési korlát betartásával:

$c_{0}^{* h}=e_{0}^{h}-\pi_{0} d_{s_{1}} \theta_{0}^{h}$,

$c_{s_{1}}^{* h}=e_{s_{1}}^{h}+d_{s_{1}} \theta_{0}^{h}-\pi_{s_{1}} d_{s_{2}} \theta_{s_{1}}^{h}$,

$c_{s_{2}}^{* h}=e_{s_{2}}^{h}+d_{s_{2}} \theta_{s_{1}}^{h}$,

ahol $\pi_{s_{t}}$ az állapotokhoz tartozó árak egyedi vektora $q_{s_{t}}^{*}$ árakból. Fontos megjegyezni, hogy $\pi_{s_{t}}$ szigorúan pozitív.

Megszorozva a (12) egyenletet $\pi_{s_{1}}$-gyel, és hozzáadva a (11) egyenlet megoldását, kapjuk:

$c_{s_{1}}^{* h}+\pi_{s_{1}} c_{s_{2}}^{* h}=e_{s_{1}}^{h}+\pi_{s_{1}} e_{s_{2}}^{h}+d_{s_{1}} \theta_{0}^{h}$.

Megszorozva a (13) egyenletet $\pi_{0}$-val, és hozzáadva a (10) egyenlet megoldását, kapjuk:

$c_{0}^{* h}+\pi_{0} c_{s_{1}}^{* h}+\pi_{0} \pi_{s_{1}} c_{s_{2}}^{* h}=e_{0}^{h}+\pi_{0} e_{s_{1}}^{h}+\pi_{0} \pi_{s_{1}} e_{s_{2}}^{h}$,

ennélfogva az eredeti hasznosságmaximalizálási problémához tartozó költségvetési korlátok a (2) egyenletben ekvivalensek a (14) egyenlettel. Következésképpen az optimális $c^{* h}$ fogyasztási terv maximalizálja az $u^{h}\left(c^{h}\right)$-t, figyelemmel a (14) feltételre. Mivel $u^{h}\left(c^{h}\right)$ szigorúan növő,

$\tilde{c}_{0}^{h}+\pi_{0} \tilde{c}_{s_{1}}^{h}+\pi_{0} \pi_{s_{1}} \tilde{c}_{s_{2}}^{h} \geq c_{0}^{* h}+\pi_{0} c_{s_{1}}^{* h}+\pi_{0} \pi_{s_{1}} c_{s_{2}}^{* h}$ 
minden $h$ esetén, szigorú egyenlőtlenséggel valamely $h$ szereplöre, aki számára szigorúan jobb a $\tilde{c}^{h}$, mint a $c^{* h}$. Összegezve ezt az összes szereplöre és felhasználva a (14) egyenletet, azt kapjuk, hogy

$\sum_{h=1}^{H} \tilde{c}_{0}^{h}+\sum_{h=1}^{H} \pi_{0} \tilde{c}_{s_{1}}^{h}+\sum_{h=1}^{H} \pi_{0} \pi_{s_{1}} \tilde{c}_{s_{2}}^{h}>e_{0}+\pi_{0} e_{s_{1}}+\pi_{0} \pi_{s_{1}} e_{s_{2}}$,

ami ellentmondásban áll azzal a feltételezéssel, hogy a fogyasztás $\tilde{c}^{h}$ allokációja megvalósítható.

Ez az állítás nagyon fontos, alátámasztásával új eredményre jutottunk. Elengedhetetlen volta a három időszakra való kiterjesztésében keresendő, ezen újonnan igazolt tulajdonság által lehetőségünk lesz a modellt is három időszakra felírni és ekkor is Pareto-optimális megoldást találni.

Amikor a piacok nem teljesek, a fogyasztás egyensúlyi elosztásai általában nem Pareto-optimálisak, és a jóléti közgazdaságtan első tétele nem lép érvénybe, ugyanis előfordulhat, hogy a szereplők nem képesek végrehajtani az optimális allokációhoz szükséges kereskedést. Az egyensúlyi fogyasztási elosztások azonban optimálisak lehetnek korlátozott értelemben. Ekkor a hatékonyság egy kevésbé ambiciózus értelmezésére térünk át. Vajon jól müködnek-e a piacok amellett, hogy az eszközpiaci forgalmon keresztül lehetetlen a szociális jólét emelése? Ha a hatékonyságot úgy értelmezzük, mint egy társadalmi tervezö által kivitelezett program végrehajtását, ahol a tervező bizonyos célokat követ, megkülönböztethetünk rövidlátó és elörelátó döntéshozó típusokat.

A fenti eredmények tükrében bizakodhatunk abban, hogy ezen korlátozott esetben is beláthatók a tárgyalt tételek, azonban ez egy későbbi kutatás tárgya. Ebben a fejezetben tehát megismertük a modell struktúráját, a következő fejezetben bemutatjuk a fogyasztási alapú CCAPM modellt.

\section{A fogyasztásalapú eszközárazás modellje}

A CAPM árazási modell a modern pénzügyi közgazdaságtan egyik népszerü témája és központi tárgya. Számtalan értekezésben kérdőjelezik meg használhatóságának körét, feltételezései szükségességét, állításai igazságát. Különlegességét mutatja az 1950-es évekre visszanyúló története és mindazok a nagy nevek, akik kutatták, újragondolták és továbbfejlesztették (French [2003]).

$\mathrm{Az}$ ismertetést a CAPM főbb vonásainak felvázolásával kezdjük, majd áttérünk a számunkra érdekfeszítőbb fogyasztási alapú eszközárazási (Consumption-Based Capital Asset Pricing) modellre.

\footnotetext{
${ }^{2}$ Angolul social planner, jelentése egy olyan gazdasági szereplő, aki úgy hozza döntését, hogy azáltal a társadalmi jólétet maximalizálja.
} 


\section{A tökepiaci eszközök árazási modellje: CAPM}

A következőkben röviden bemutatjuk a tőkepiaci eszközárazási modellt Bodie és szerzötársai [2011] 9. fejezete alapján. A tőkepiaci eszközárazási modell - amelyre szinte mindig CAPM-ként hivatkozik az irodalom - pontos becslést ad egy adott eszköz kockázata és várható hozama közti kapcsolatra. E kapcsolatnak két létfontosságú funkciója van.

A tőkepiaci eszközárazási modell tulajdonképpen a kockázatos eszközök egyensúlyi várható hozamára vonatkozó becslések összessége. A modern portfóliókezelés alapjait Markowitz [1952] fektette le. A konkrét CAPM-et csak 12 évvel később hozták létre, a kifejlesztéséhez három cikk kapcsolható: Sharpe [1964], Lintner [1965], Mossin [1966].

A CAPM modell feltevéseit és állításait jelen tanulmányban nem részletezzük, mindezek elolvashatók Bodie és szerzőtársai [2011]-ben, de ebből a kötetből kiemelünk néhány elméleti pontot.

A modell feltételei szerint egy értékpapírból származó várható hasznosság csak az adott értékpapír hozamának várható értékétől és szórásától függ. A piaci portfólió kockázati prémiuma megadható a kockázatának és a reprezentatív befektető kockázatkerülési mértékének az arányában:

$E\left(r_{M}\right)-R_{f}=\bar{A} \sigma_{M}^{2}$,

ahol $r_{M}$ a piaci hozam, $R_{f}$ a kockázatmentes hozam, $\sigma_{M}^{2}$ a piaci portfólió varianciája és $\bar{A}$ az alanyok általános kockázatelutasításának mértéke. Az egyedi pénzügyi eszközök kockázati prémiuma arányos a piaci portfólió kockázati prémiumával, valamint az értékpapír béta koefficiensével. A béta egyfajta mérték, amely azt mutatja, hogy az értékpapír hozama és a piaci hozam mennyire mozog együtt:

$\beta_{j}=\frac{\operatorname{cov}\left(r_{j}, r_{M}\right)}{\sigma_{M}^{2}}$,

és a kockázati prémium az egyedi értékpapírok esetén:

$E\left(r_{j}\right)-R_{f}=\frac{\operatorname{cov}\left(r_{j}, r_{M}\right)}{\sigma_{M}^{2}}\left[E\left(r_{M}\right)-R_{f}\right]=\beta_{j}\left[E\left(r_{M}\right)-R_{f}\right]$.

A CAPM egyik legnépszerübb módja a várható hozam-béta kapcsolat vizsgálata. Ha ez a mutató igaz egyedi eszközökre, akkor igaznak kell lennie az eszközök bármely kombinációjára is. Ezt a kapcsolatot tekinthetjük úgy, mint egy jutalom-kockázat egyenletet. Az eszközbéta jól mutatja a kockázatot, mert arányos azzal a kockázattal, amivel az értékpapír hozzájárul az optimális kockázatú portfólióhoz. A várható hozam-béta kapcsolat grafikus ábrázolása az értékpapírpiaci egyenes (security market line, SML).

\section{CCAPM, avagy a fogyasztásalapú eszközárazás}

A fogyasztási alapú eszközárazás modelljét (CCAPM) szintén a Bodie és szerzötársai [2011]-ben található dokumentáció segítségével prezentáljuk. A CAPM középpontjába most közvetlenül a fogyasztás kerül. Először ilyen modelleket Rubinstein [1976], 
Lucas [1978] és Breeden [1979] hoztak létre. Egy élethosszig tartó fogyasztási tervet veszünk, ahol a szereplőknek minden periódusban dönteniük kell vagyonuk felosztásáról a mai fogyasztás, valamint a jövőbeli fogyasztást biztosító megtakarítások és befektetések között. Akkor érünk el optimumot, ha a mai napon egy pótlólagos pénzegység hasznossága megegyezik annak a várható jövőbeli fogyasztásnak a hasznosságával, amelyet ugyanezzel a pótlólagos pénzegységgel finanszírozunk. Az általános modellekben a munkabér és az optimális teljes portfólióba fektetett pénzegységek hozama növelheti a jövőbeli vagyont.

Egy pénzügyi eszköz a fogyasztást tekintve kockázatosabb, ha a kovarianciája a fogyasztás növekedésével pozitív értéket vesz fel. Más szavakkal, a kifizetése akkor magasabb, amikor a fogyasztás szintje már magas, és akkor alacsonyabb, amikor a fogyasztás relatíve korlátozott. ${ }^{3}$ Ebből adódóan azon eszközök esetében magasabbak az egyensúlyi kockázati prémiumok, amelyek magasabb kovarianciát mutatnak a fogyasztás növekedésével. Ez alapján egy értékpapír kockázati prémiuma a fogyasztás kockázatának függvénye lesz:

$E\left(R_{j}\right)=\beta_{j C}\left[E(r c)-R_{f}\right]$

ahol a $C$ portfólió értelmezhető fogyasztáskövető portfólióként, amely a fogyasztásnövekedéssel járó legmagasabb korrelációjú portfólió. A $\beta_{j C}$ a j-edik eszköz $R_{j}$ többlethozamaira felírt regressziós egyenes meredekségi együtthatója, azaz a regressziós függvény magyarázó változói a fogyasztáskövető portfólió többlethozamai. A korábban már definált $R_{f}$ kockázatmentes hozammal pedig az $\left[E(r c)-R_{f}\right]$ kifejezés a fogyasztás bizonytalanságától függő kockázati prémium, amelyet szintén a fogyasztáskövető portfólió várható többlethozama határoz meg.

Látható, hogy mennyire hasonlít ez a hagyományos CAPM-hez. A fogyasztáskövető portfólió játssza a CAPM piaci portfóliójának a szerepét. Az eredeti tökepiaci eszközárazási modellel szemben azonban a CCAPM-ben a piaci portfólió megfelelőjének bétája nem feltétlenül 1, sőt teljes mértékben életszerü és empirikusan alátámasztott, hogy ez a béta nagyobb 1-nél. Ez azt jelenti, hogy a lineáris kapcsolat a piaci index kockázati prémiuma és a fogyasztási portfólió között:

$E\left(R_{M}\right)=\alpha_{M}+\beta_{M C} E\left(R_{C}\right)+\varepsilon_{M}$,

ahol $\alpha_{M}$ és $\varepsilon_{M}$ biztosítja a lehetőséget az empirikus elhajlásokra az egzakt (20) egyenlettel felírt modelltől, és a $\beta_{M C}$ nem feltétlenül egyenlö 1-gyel.

A fogyasztásalapú pénzügyi eszközárazás modelljének vonzereje az, hogy kompakt módon magában hordozza a fogyasztás fedezetének lehetöségét (consumption hedging) és a befektetési lehetőségek lehetséges változásait; mindezt beépítve a hozamok eloszlásának paraméterébe egy egytényezős keretrendszerben.

Rövid összefoglalásképp tehát felírjuk a CCAPM egyfajta definícióját.

4. DEFINícıó • A fogyasztásalapú tőkepiaci eszközárazási modell (CCAPM) egy egytényezős modell, amelyben a piaci portfólió többlethozamát a fogyasztáskövető

\footnotetext{
${ }^{3}$ Erre felhívjuk a figyelmet a három időszakos modell kifejtése során is.
} 
portfólió többlethozamával helyettesítjük. Ez a modell a befektetőknek a fogyasztás változására való érzékenységével hozza összefüggésbe a pénzügyi eszközök kockázatát.

\section{CAPM-egyenlet három időszakra}

A következőkben bebizonyítjuk, hogy a $\beta$ árazási formula, amely egy kockázatos eszköz hozamát hasonlítja a piaci portfólió hozamához, levezethető három időszakos pénzügyi általános egyensúlyelméleti modellből is. Jóllehet a CAPM különböző szituációkban (hiányzó feltételek, különböző környezet) való megtestesülése meganynyi publikáció témáját képezte már, ez a megközelítés egyedinek tekinthető. A tőkepiaci eszközárazási modellt az eddigiek során nem terjesztették ki három időszakra, és ennek igazolása jövőbeli kutatásokra vár, felveti a CAPM hosszú távra való alkalmazhatóságának lehetőségét is.

A jelöléseket és a gazdasági környezetet a tanulmány elején már ismertettük. A döntéshozók optimalizálási folyamatának közgazdaságtani és matematikai felírásához, valamint a további egyenletek levezetéséhez LeRoy-Werner [2001] megfelelö részeire támaszkodtunk.

Ahogyan az általános modellek felépítése a közgazdaságtanban, a mienk is a hasznossági függvény felírásával indul. Ennek megfelelően a $h$ véges számú racionális egyén hasznossági függvénye

$u^{h}\left(c^{h}\right)=v_{0}^{h}\left(c_{0}^{h}\right)+\delta_{1} \sum_{s_{1} \in \mathcal{S}_{1}} \rho_{s_{1}} v_{s_{1}}^{h}\left(c_{s_{1}}^{h}\right)+\delta_{1} \delta_{2} \sum_{s_{1} \in \mathcal{S}_{1}} \rho_{s_{1}} \sum_{s_{2} \in \mathcal{S}_{1}^{+}} \rho_{s_{2}} v_{s_{2}}^{h}\left(c_{s_{2}}^{h}\right)$

amelyet maximalizálni szeretnénk. A maximalizálás azonban több feltételhez is kötve van: egy személy nem fogyaszthat végtelen mennyiséget, mert adott nagyságú készletei, bevételei és akár költségei is vannak. A költségvetési korlátokkal már találkozhattunk is, a (3) és a (4) egyenletek írják le ezeket.

A hasznossági függvény feltételekhez kötött maximalizálásához a Lagrangemódszert használjuk, ahol $\lambda_{s_{t}}^{h}$-val jelöljük a Lagrange-multiplikátorokat. Ez az eljárás hatékonynak bizonyul a függvények szélsőértékének megkeresésében, miközben biztosítja, hogy a megkötések is teljesüljenek, ezért lesz számunkra is alkalmas. A Lagrange-függvény, ha a hasznossági függvényt maximalizáljuk, és a költségvetési korlátok a feltételek, a következö:

$\mathcal{L}^{h}=u^{h}\left(c^{h}\right)-\lambda_{0}^{h}\left(c_{0}^{h}-e_{0}^{h}+q_{0} \theta_{0}^{h}\right)-\lambda_{s_{1}}^{h}\left(c_{s_{1}}^{h}+q_{s_{1}} \theta_{s_{1}}^{h}-e_{s_{1}}^{h}-d_{s_{1}} \theta_{0}^{h}\right)-$

$-\lambda_{s_{2}}^{h}\left(c_{s_{2}}^{h}-e_{s_{2}}^{h}-d_{s_{2}} \theta_{s_{2}^{-}}^{h}\right)$.

Ennek a függvénynek kell a változók $\left(c_{0}^{h}, c_{s_{1}}^{h}, c_{s_{2}}^{h}, \theta_{0}^{h}, \theta_{s_{1}}^{h}\right)$ szerint vett parciális deriváltjait egyenlővé tenni nullával, és ezáltal jut a fogyasztó optimumra (a parciális deriváltakat lásd a Függelékben).

A parciális deriváltakat megoldjuk $q_{s_{t}}$-re: 
$q_{s_{t}}=A_{s_{t}} \frac{\lambda_{s_{t}^{+}}^{h}}{\lambda_{s_{t}}^{h}}$, feltéve, hogy $\lambda_{s_{t}}^{h} \neq 0$,

majd behelyettesítjük a $\lambda^{h}-\mathrm{k}$ megfelelő értékét:

$q_{s_{t}}=A_{s_{t}} \frac{\delta_{t+1} \sum_{s_{t^{+}} \in s_{t}^{+}} \rho_{s_{t}^{+}} \partial v_{s_{t}^{+}}^{h}\left(c_{s_{t}^{+}}^{h}\right) / \partial c_{s_{t}^{+}}^{h}}{\partial v_{s_{t}}^{h}\left(c_{s_{t}}^{h}\right) / \partial c_{s_{t}}^{h}}$

és ezzel, ahogy az majd látható lesz, megkapjuk a különböző időszakok fogyasztása közötti helyettesítési határrátát (Marginal Rate of Substitutions, MRS). A (25) egyenlet azt jelenti, hogy bármely $h$ alany minden egyes $s_{t} \in\{0\} \cup \mathcal{S}_{1}$ világállapotban úgy fektet be minden $j$-edik pénzügyi eszközbe, hogy egy pótlólagosan hozzáadott egység $q_{s_{t}, j}$ határköltsége egyenlö legyen a határhasznával, amely pedig $h$ szereplö jövőbeli osztalékainak jelenértéke.

A várható érték korábbiakban leírt definíciója alapján behelyettesítünk a (25)

$q_{s_{t}}=\frac{\delta_{t+1} E_{s_{t}}\left[\partial_{c_{s_{t}}} v_{s_{t}^{h}}^{h}\left(c^{h *}\right) A_{s_{t}}\right]}{\partial_{c_{s_{t}}} v_{s_{t}}^{h}\left(c^{h *}\right)}=E\left(M R S_{s_{t}}^{h} A_{s_{t}}\right), \quad$ minden $\quad s_{t} \in\{0\} \cup \mathcal{S}_{1}$,

ezáltal már meg is jelent az $M R S$, amely a $t$-edik időpontbeli és a $t^{+}$-adikidőponthoz tartozó összes állapotbeli fogyasztások között értelmezett. A helyettesítési határráta kapcsán ki kell emelnünk, hogy az egyes fogyasztókhoz tartozó MRS-ek akár különbözhetnek is, a hasznossági függvény alakjából adódóan (például kockázathoz való viszonyuktól függően), azonban egyensúlyban ezeknek meg kell egyezniük. Ennek az egyezőségnek az eredményeként a teljes piacok feltételezésével egyetlen árat kapunk, amely nem más, mint a (26) egyenletben meghatározott ár. A $q_{s_{t}}$ eszközárakhoz definiáljuk az $r_{s_{t}^{+}, \theta_{s_{t}}}$ egy időszakos hozamot olyan $\theta_{s_{t}}^{h}$ portfólióra, amelyre $q_{s_{t}} \theta_{s_{t}}^{h} \neq 0$ teljesül, az alábbi módon:

$r_{s_{t}^{+}, \theta_{s_{t}}}=\frac{A_{s_{t}} \theta_{s_{t}}^{h}}{q_{s_{t}} \theta_{s_{t}}^{h}}$

A hozam (27) képlete mutatja az általánosan is adódó meghatározást: a portfólió értékpapírjainak kifizetését osztjuk azok árával. Már csak egy fogalom szükséges ahhoz, hogy levezethessük a fogyasztásalapú eszközárazás egyenletét, és ez a kovariancia. Ennek csak a megszokott értelmezésével fogunk találkozni:

$E(y z)=\operatorname{cov}(y, z)+E(y) E(z)$

formulát alkalmazzuk. Ezekkel a (26) egyenlet már átírható:

$1=\frac{\delta_{t+1} E_{s_{t}}\left[\partial_{c_{s_{t}}} v_{s_{t}^{+}}^{h}\left(c^{h *}\right) r_{s_{t}^{+}, \theta_{s_{t}}}\right]}{\partial_{c_{s_{t}}} v_{s_{t}}^{h}\left(c^{h *}\right)}$

${ }^{4}$ A jelölés egyszerüsítése céljából a továbbiakban egy $f(x)$ függvény $x$ változója szerint vett parciális deriváltját a megszokott $\partial f(x) / \partial x$ helyett $\partial_{x} f(x)$ módon jelöljük. 
amelyhez felhasználva a fenti definíciókat és a $\operatorname{cov}_{s_{t}}\left(x_{s_{t}^{+}}, y_{s_{t}^{+}}\right)$kifejezést a feltételes kovariancia jelölésére két változó között, az

$$
1=\frac{\delta_{t+1} E_{s_{t}}\left(r_{s_{t}^{+}, \theta_{s_{t}}}\right) E_{s_{t}}\left[\partial_{c_{s_{t}^{+}}} v_{s_{t}^{+}}^{h}\left(c^{h *}\right)\right]}{\partial_{c_{s_{t}}} v_{s_{t}}^{h}\left(c^{h *}\right)}+\frac{\delta_{t+1} \operatorname{cov}_{s_{t}}\left[\partial_{c_{s_{t}}} v_{s_{t}^{+}}^{h}\left(c^{h *}\right), r_{s_{t}^{+}, \theta_{s_{t}}}\right]}{\partial_{c_{s_{t}}} v_{s_{t}}^{h}\left(c^{h *}\right)}
$$

egyenletet kapjuk, amelynek átrendezését követően jutunk a várható egy időszakos hozam:

$E_{s_{t}}\left(r_{s_{t}^{+}, \theta_{s_{t}}}\right)=\frac{\partial_{c_{s_{t}}} v_{s_{t}}^{h}\left(c^{h *}\right)}{\delta_{t+1} E_{s_{t}}\left[\partial_{c_{s_{t}^{+}}} v_{s_{t}^{+}}^{h}\left(c^{h *}\right)\right]}-\frac{\operatorname{cov}_{s_{t}}\left[\partial_{c_{s_{t}^{+}}} v_{s_{t}^{+}}^{h}\left(c^{h *}\right), r_{s_{t}^{+}, \theta_{s_{t}}}\right]}{E_{s_{t}}\left[\partial_{c_{s_{t}^{+}}} v_{s_{t}^{+}}^{h}\left(c^{h *}\right)\right]}$

leírására, ahol az

$$
R_{s_{t}}^{f}=\frac{\partial_{c_{s_{t}}} v_{s_{t}}^{h}\left(c^{h *}\right)}{\delta_{t+1} E_{s_{t}}\left[\partial_{c_{s_{t}^{+}}} v_{s_{t}^{+}}^{h}\left(c^{h *}\right)\right]}
$$

kifejezés a kockázatmentes eszköz egyperiódusos hozama. ${ }^{5}$ Ezzel és a (31) egyenlettel adódik a fogyasztásalapú eszközárazás egyenlete:

$E_{s_{t}}\left(r_{s_{t}^{+}, s_{s_{t}}}\right)=R_{s_{t}}^{f}-\delta_{t+1} R_{s_{t}}^{f} \frac{\operatorname{cov}_{s_{t}}\left[\partial_{c_{s_{t}^{+}}} v_{s_{t}^{+}}^{h}\left(c^{h *}\right), r_{s_{t}^{+}, s_{s_{t}}}\right]}{\partial_{c_{s_{t}}} v_{s_{t}}^{h}\left(c^{h *}\right)}$.

Ez az egyenlet azt mutatja, hogy a kockázati prémium (ami a várható hozam és a kockázatmentes kamatláb különbsége) minden eszköz esetében arányos kamatlábának és az $s_{t}$ és $s_{t}^{+}$világállapotok közti helyettesítési határrátának a kovarianciájával (negatív arányossági állandóval). Szigorúan véve a $\partial_{c_{s_{t}}} v_{s_{t}^{+}}^{h}\left(c^{h *}\right) / \partial_{c_{s_{t}}} v_{s_{t}}^{h}\left(c^{h *}\right)$ a (33) egyenletben nem az $s_{t}^{+}$és az $s_{t}$ kimenetek állapottól függö fogyasztása közötti helyettesítési határráta, mivel hiányoznak a valószínűségek. Hasonlóképpen a továbbiakban is a fogyasztás határhasznosságaként fogunk hivatkozni a $\partial_{c_{s_{t}}} v_{s_{t}^{+}}^{h}\left(c^{h *}\right)$ kifejezésre, a valószínüségek hiánya ellenére. Nincs azonban oka annak, hogy ennél a terminológiai pontatlanságnál megtorpanjunk, ugyanis nem szakadunk el a pénzügyi-közgazdasági irodalomban szokásos módtól (LeRoy-Werner [2001]).

Egy szigorúan kockázatkerülö döntéshozót tekintve a $\partial_{c_{s_{t}^{+}}} v_{s_{t}^{+}}^{h}\left(c^{h *}\right)$ az $s_{t}^{+}$-beli fogyasztás csökkenő függvénye. Ezért annak az értékpapírnak, amely magas kifizetésü, ha a fogyasztás magas, és alacsony kifizetésü, amikor a fogyasztás is alacsony, a várható hozama meghaladja a kockázatmentes értékpapírét. Vegyünk egy eszközt, amelynek akkor magas a kifizetése, amikor a fogyasztás alacsony, és akkor alacsony a kifizetése, amikor a fogyasztás magas! A fenti gondolatmenetet folytatva, egy ilyen eszköz várható hozama kisebb lesz, mint a kockázatmentes hozam. Ilyen értékpapírok felhasználhatók arra, hogy csökkentsék a szereplő fogyasztásának a kockázatát. A viszonylag alacsony hozam

\footnotetext{
${ }^{5}$ A kockázatmentes eszköz hozamára a LeRoy-Werner [2001]-ben található $R_{s_{t}}^{f}=1 / \sum_{s_{t} \in\{0\} \cup \mathcal{S}_{1} \cup \mathcal{S}_{2}} q_{s_{t}}$ definíciót használjuk, amely egyensúlyban megegyezik a levezetésbeli $R_{s_{t}}^{f}$-fel.
} 
viszonylag magas árat tükröz. Az az eszköz, amely hozamának az MRS-sel vett kovarianciája nulla, a kockázatmentes értékpapírral egyenlő várható hozamú lesz.

A (33) egyenlet alapján egy értékpapír kockázati prémiuma kizárólag a hozama és az $s_{t}$ és $s_{t}^{+}$közti helyettesítési határráta kovarianciájától függ. Ez a kovariancia az értékpapír kockázatának mértékeként értelmezhető, amelynek két szokatlan tulajdonságát érdemes kiemelni. Egyrészt csak akkor használható, ha egyensúlyban van a gazdaság. Másrészt viszont ez a kovarianciamérték nemcsak részleges, hanem teljes rendezését adja a hozamok kockázatának.

Ha a helyettesítési határráta állandó, a fogyasztásalapú eszközárazás a (33) képlet szerinti értelemben fair árat (tisztességes árat) szab meg. Két szituációban lehet az MRS determinisztikus: ha a szereplö fogyasztása is determinisztikus, és ha a szereplö kockázatsemleges.

Ismerjük meg most az egyén optimalizálásának további részleteit, amihez a következő feltételben bemutatjuk a $v_{s_{t}}^{h}$ hasznossági függvények $(t+1)$-edik időszaki fogyasztásban kvadratikus alakját.

2. FELTÉTEL • Legyen minden fogyasztó Bernoulli-függvénye a következő kvadratikus hasznossági függvény:

$v_{s_{t}}^{h}\left(c_{s_{t}}^{h}\right)=\xi_{t} c_{s_{t}}^{h}-1 / 2 \alpha_{t}\left(c_{s_{t}}^{h}\right)^{2}$.

Behelyettesítve ennek deriváltjait a (33) eszközárazási egyenletbe, azt kapjuk, hogy

$E_{s_{t}}\left(r_{s_{t}^{+}, \theta_{s_{t}}}\right)=R_{s_{t}}^{f}-\delta_{t+1} R_{s_{t}}^{f} \frac{\operatorname{cov}_{s_{t}}\left(\xi_{t+1}-\alpha_{t+1} c_{s_{t}^{+}}^{h}, r_{s_{t}^{+}, \theta_{s_{t}}}\right)}{\xi_{t}-\alpha_{t} c_{s_{t}}^{h}}$,

amiből következően egy tetszőleges j-edik eszköz várható hozamára is felírható:

$E_{s_{t}}\left(r_{s_{t}^{+}, j}\right)=R_{s_{t}}^{f}+\frac{\delta_{t+1} \alpha_{t+1} R_{s_{t}}^{f}}{\xi_{t}-\alpha_{t} c_{s_{t}}^{h}} \operatorname{cov}_{s_{t}}\left(c_{s_{t}^{+}}^{h}, r_{s_{t}^{+}, j}\right)$.

Egy értékpapírpiaci gazdaságban (securities market economy) az aggregált készlet az eszközök kifizetései által generált altérben (asset span) van, ami azt jelenti, hogy ez elérhető valamely értékpapírokból álló portfólió kifizetéseként. Ezt a portfóliót nevezzük piaci portfóliónak, amelynek hozamát jelöljük $r_{s_{t}^{+}}^{M}$-mel. A (35) egyenlet portfóliók hozamára is alkalmazható. Kiváltképp alkalmazható az $r_{s_{t}^{+}}^{M}$ piaci hozamra, és ezért

$E_{s_{t}}\left(r_{s_{t}^{+}}^{M}\right)=R_{s_{t}}^{f}+\frac{\delta_{t+1} \alpha_{t+1} R_{s_{t}}^{f}}{\xi_{t}-\alpha_{t} c_{s_{t}}^{h}} \operatorname{cov}_{s_{t}}\left(c_{s_{t}^{+}}^{h}, r_{s_{t}^{+}}^{M}\right)$

is helytálló. Elosztjuk a (35) egyenletet a (36) egyenlettel, miután az $R_{s_{f}}^{f}$ levonásra került mindkettőből, ezáltal elhagyjuk a $\delta_{t+1} \alpha_{t+1} R_{s_{t}}^{f} /\left(\xi_{t}-\alpha_{t} c_{s_{t}}^{h}\right)$ kifejezést, és az

$$
\frac{E_{s_{t}}\left(r_{s_{t}^{+}, j}\right)-R_{s_{t}}^{f}}{E_{s_{t}}\left(r_{s_{t}^{+}}^{M}\right)-R_{s_{t}}^{f}}=\frac{\operatorname{cov}_{s_{t}}\left(c_{s_{t}^{+}}, r_{s_{t}^{+}, j}\right)}{\operatorname{cov}_{s_{t}}\left(c_{s_{t}^{+}}, r_{s_{t}^{+}}^{M}\right)}
$$

egyenlethez jutunk, feltéve, hogy a piaci kockázati prémium nem nulla. 
Ha az egyensúlyi fogyasztás a piaci és a kockázatmentes értékpapírok kifizetései által generált altérben van, akkor $c_{s^{+}}^{h}$ és $r_{s_{t}^{+}}^{M}$ tökéletesen korrelálnak. Ennek megfelelöen $c_{s_{t}^{+}}^{h}$ helyettesíthetö $\varphi r_{s_{t}^{+}}^{M}$-mel. Végül, egy $\theta_{s_{t}}^{h} \in \mathbb{R}^{s_{s_{t}}}$ portfólióra definiáljuk $\beta_{\theta_{s_{t}}}$-t:

$\beta_{\theta_{s_{t}}}=\frac{\operatorname{cov}_{s_{t}}\left(r_{s_{t}^{+}}^{M}, r_{s_{t}^{+}, \theta}\right)}{\operatorname{var}\left(r_{s_{t}^{+}}^{M}\right)}$.

Ez a $\beta_{\theta_{s}}$ lesz a CCAPM modell korábban is említett fogyasztási bétája, amely egy adott pénzügyi eszköz kockázatának viszonyát mutatja a piaci kockázathoz.

Most, hogy már minden szükséges eszközünk és egyenletünk megvan hozzá, láthatjuk, hogy a (39) CAPM árazó formula minden $\theta_{s_{t}}^{h} \in \mathbb{R}^{J_{s_{t}}}$ esetén fennáll, tehát

$E_{s_{t}}\left(r_{s_{t}^{+}, \theta}\right)-R_{s_{t}}^{f}=\beta_{\theta_{s_{t}}}\left[E_{s_{t}}\left(r_{s_{t}^{+}}^{M}\right)-R_{s_{t}}^{f}\right]$,

amely nem más, mint a CAPM értékpapírpiaci egyenesének (security market line) egyenlete:

$E_{s_{t}}\left(r_{s_{t}^{+}, \theta}\right)=R_{s_{t}}^{f}+\beta_{\theta_{s_{t}}}\left[E_{s_{t}}\left(r_{s_{t}^{+}}^{M}\right)-R_{s_{t}}^{f}\right]$.

A feltevés, amely szerint az egyensúlyi fogyasztás a piaci és a kockázatmentes értékpapírok kifizetése által generált altérben van, triviális egyetlen reprezentatív szereplös gazdaságban (representative-agent economy), mivel ekkor minden egyes döntéshozó egyensúlyi fogyasztása egyenlő a piaci portfólió kifizetésének egy főre jutó részével. Mivel feltettük, hogy mindenkinek ugyanolyan kvadratikus hasznossági függvénye van, ezért ez az általunk felvázolt gazdaságra is igaz.

Ezáltal beláttuk, hogy a három időszakos haszonmaximalizálási modellből is levezethetö a jól ismert CCAPM - azaz a szakirodalomban eddig ismert két időszakos modell eredményeit kiterjesztettük egy három időszakos modellre. Ez az eredmény önmagában is komoly jelentőségü, de alapjául szolgálhat számos későbbi kutatásnak, amelyeknek alapkövetelménye egy több időszakos modell, ilyen például a hosszú lejáratú értékpapírok elemzése vagy a nem teljes piacok hosszú távú hatékonyságának kérdése is.

\section{Hivatkozások}

Bodie, Z.-Kane, A.-Marcus, A. J. [2011]: Investments. 9. kiadás, McGraw-Hill/Irwin, New York, 9. fejezet.

BREEDEN, D. [1979]: An intertemporal asset pricing model with stochastic consumption and investment opportunities. Journal of Financial Economics, Vol. 7. No. 3. 265-296. o. https:// doi.org/10.1016/0304-405X(79)90016-3.

French, C. W. [2003]: The treynor capital asset pricing model. Journal of Investment, Management, Vol. 1. No. 2. 60-72. o.

Habis Helga-Herings, J.-J. [2011]: Core concepts for incomplete market economies. Journal of Mathematical Economics, Vol. 47. No. 5. 595-609. o. https://doi.org/10.1016/j. jmateco.2011.07.005. 
LeRoy, S. F.-Werner, J. [2001]: Principles of Financial Economics. Cambridge University Press, Cambridge-New York, https://doi.org/10.1017/cbo9780511753787.

LINTNER, J. [1965]: The valuation of risk assets and the selection of risky investments in stock portfolios and capital budgets. Review of Economics and Statistics, Vol. 47. No. 1. 13-37. o. https://doi.org/10.2307/1924119.

LuCAS, R. [1978]: Asset prices in an exchange economy. Econometrica, Vol. 46. 1429-1445. o. https://doi.org/10.2307/1913837.

MagiLl, M.-QuinziI, M. [1996]: Theory of Incomplete Markets. Vol. 1. Massachusetts Institute of Technology, Cambridge-London.

Markowitz, H. [1952]: Portfolio selection. The Journal of Finance, Vol. 7. No. 1. 77-91. o. https://doi.org/10.2307/2975974.

Mossin, J. [1966]: Equilibrium in a capital asset market. Econometrica, Vol. 34. No. 4. 768-783. o. https://doi.org/10.2307/1910098.

Rubinstein, M. [1976]: The valuation of uncertain income streams and the pricing of options. The Bell Journal of Economics and Management Science, Vol. 7. 407-425. o. https://doi. org/10.2307/3003264.

SHARPE, W. [1964]: Capital asset prices: A theory of market equilibrium under the conditions of risk. The Journal of Finance, Vol. 19. No. 3. 425-442. o. https://doi.org/10.2307/2977928.

\section{Függelék}

\section{Parciális deriváltak}

A racionális fogyasztó Lagrange-függvényének parciális deriváltjai, amelyeket egyenlővé teszünk nullával:

$$
\begin{aligned}
& \frac{\partial \mathcal{L}^{h}}{\partial c_{0}^{h}}=\frac{\partial v_{0}^{h}\left(c_{0}^{h}\right)}{\partial c_{0}^{h}}-\lambda_{0}^{h}=0, \\
& \frac{\partial \mathcal{L}^{h}}{\partial c_{s_{1}}^{h}}=\frac{\delta_{1} \sum_{s_{1} \in S_{1}} \rho_{s_{1}} \partial v_{s_{1}}^{h}\left(c_{s_{1}}^{h}\right)}{\partial c_{s_{1}}^{h}}-\lambda_{s_{1}}^{h}=0, \\
& \frac{\partial \mathcal{L}^{h}}{\partial c_{s_{2}}^{h}}=\frac{\delta_{1} \delta_{2} \sum_{s_{1} \in S_{1}} \rho_{s_{1}} \sum_{s_{2} \in S_{1}^{+}} \rho_{s_{2}} \partial v_{s_{2}}^{h}\left(c_{s_{2}}^{h}\right)}{\partial c_{s_{2}}^{h}}-\lambda_{s_{2}}^{h}=0, \\
& \frac{\partial \mathcal{L}^{h}}{\partial \theta_{0}^{h}}=-\lambda_{0}^{h} q_{0}+d_{s_{1}} \lambda_{s_{1}}^{h}=0, \\
& \frac{\partial \mathcal{L}^{h}}{\partial \theta_{s_{1}}^{h}}=-\lambda_{s_{1}}^{h} q_{s_{1}}+d_{s_{2}} \lambda_{s_{2}}^{h}=0 .
\end{aligned}
$$

A fogyasztás szerinti deriváltak ekvivalensek a

$$
\Delta u^{h}\left(c^{h *}\right)=\lambda^{h *}
$$


A TÖKEPIACI ESZKÖZÁRAZÁSI MODELL HÁROM IDÖSZAKOS ... 393

mátrixegyenlettel, ami azt jelenti, hogy $t=0$-ban a Lagrange-multiplikátorok a hasznossági függvény megfelelő világállapothoz tartozó fogyasztás szerinti parciális deriváltjaival egyenlők. A portfólióállomány szerinti deriváltak pedig a

$-q_{s_{t}} \lambda_{s_{t}}^{h}+A_{s_{t}} \lambda_{s_{t}^{+}}^{h}=0, \quad \forall s_{t} \in\{0\} \cup \mathcal{S}_{1}$

egyenlettel megfeleltethetők. 